Journal of Engineering and Applied Sciences 14 (Special Issue 9): 10572-10578, 2019

ISSN: 1816-949X

(C) Medwell Journals, 2019

\title{
The Quality of Drinking Water Bottled Domestic and Imported in Iraq
}

\author{
${ }^{1,2}$ Amjad Hussein and ${ }^{2,3}$ Ruqayah Mohammed \\ ${ }^{1}$ Department of Civil Engineering, College of Engineering, \\ Al-Muthanna University, Al-Muthanna, Samawah, Iraq \\ ${ }^{2}$ Civil Engineering Research Group, School of Computing, Science and Engineering, \\ University of Salford, Newton Building, Peel Park Campus, Salford, \\ Greater Manchester M5 4WT, United Kingdom \\ ${ }^{3}$ Department of Civil Engineering, Faculty of Engineering, University of Babylon, Hilla, Iraq
}

\begin{abstract}
Assess the quality of 10 kinds of imported water and 5 domestic varieties of bottled drinking water during the first half of 2017 in the city of Samawah, Iraq and the results compared with the attributes of bottled drinking water issued by the Saudi Arabian Standards Organization standards for the lack of standard special Iraqi drinking bottled water. Evaluation criteria included the physical and chemical the following: $\mathrm{pH}$, turbidity, total dissolved solids, total hardness, calcium, magnesium, sodium, fluoride, nitrates, sulfates, chlorides, iron, manganese. Results showing that the levels of water quality standards of domestic and imported brands were identical to different specifications with the exception of dissolved solids in the category of one domestic and one imported brand and fluoride in all varieties and types of domestic importers. Measurements also revealing explosives that have been selected for each item of different types of variation in the values of water standards explosives with rates ranging from $0-35 \%$ for domestic brand and $0-100 \%$ for imported brand and the values of most of the criteria listed on the packaging does not reflect the actual content of the water bombs.
\end{abstract}

Key words: Water bottled, environment, packaging, domestic, brands, nitrates

\section{INTRODUCTION}

The most important characteristic of bottled drinking water when compared it with tap water is the quality of bottled water, particularly in terms of taste and the regularity of water quality over time (Huerta-Saenz et al., 2012; Johnstone and Serret, 2012) and the tap water of the networks may change as a result of the materials they are exposed from the surrounding environment from reservoirs and pipes that pass in before they reach the consumer while the probability of contamination of bottled water is very low because it is placed in sealed packaging.

A 4 year study in the United States, reported by US Natural Resources Defense Council in which more than 1,000 packages covering 104 items of bottled drinking water were screened in some states, revealed that bottled water is not necessarily more pure or safe than tap water with about $33 \%$ of the bottled water at least one of them has different contaminants including some organic chemicals and bacteria at levels higher than permitted in the specifications of bottled drinking water and the results showed that about $25 \%$ of bottled water is actually a tap water that has been bottled after further treatment or without treatment, according to the survey, the main reason for the growing consumption of bottled drinking water in the US States is the marketing and promotional means used by some manufacturers to persuade the costumer of the purity and safety of bottled water, exploiting the anxiety and suspicions of people about the quality and safety of the water networks.

In Iraq, the drinking water industry, packed over the past 20 years has grown significantly and has a high production capacity and bottled water is available in different sizes, most of which are used for one time and items imported from different countries are available on the local market. This research aims to assess the water quality of five domestic produced bottled drinking water and ten imported bottled drinking. The assessment included the following comparison of results with international standards for bottled drinking water Comparing the quality of domestic varieties with the quality of imported items comparing the results with the water content on the packaging and assessment of the difference in water quality between packaging of each item.

Corresponding Author: Amjad Hussein, Department of Civil Engineering, College of Engineering, Al-Muthanna University, Al-Muthanna, Samawah, Iraq 
J. Eng. Applied Sci., 14 (Special Issue 9): 10572-10578, 2019

\begin{tabular}{|c|c|}
\hline \multicolumn{2}{|c|}{ Abbreviations: } \\
\hline I & Imported \\
\hline KSA : & The Kingdom Saudi Arabia \\
\hline NBOS : & Number of Bottled Out of Standard \\
\hline Mn : & Manganese \\
\hline $\mathrm{Fe}$ & Iron \\
\hline $\mathrm{Cl}$ & Chloride \\
\hline $\mathrm{NO}_{3}$ & Nitrate \\
\hline $\mathrm{F}$ & Fluoride \\
\hline $\mathrm{Na}$ & Sodium \\
\hline $\mathrm{So}_{4}$ & Sulphates \\
\hline $\mathrm{Mg}$ & Magnesium \\
\hline $\mathrm{CaCO}_{3}:$ & Calcium Carbonate \\
\hline $\mathrm{Ca} \quad$ : & Calcium \\
\hline TDS : & Total Dissolved Solids \\
\hline TU & Turbidity \\
\hline
\end{tabular}

\section{MATERIALS AND METHODS}

Samples collection method: The process of obtaining bottled drinking water packages from some of the city's shops randomly during the first half of 2018, taking into account the fact that the factory production date for packaging taken from the same packaging to avoid the possibility of a change in the characteristics of the water with the expiry of the packaging. The water quality analysis was performed according to APHA., (1995) Hussein (2017) and Hussein and Scholz (2017), unless stated otherwise. Two packages of each item were purchased and the physical and chemical characteristics were measured twice per item to confirm the accuracy of the measurement. The spectrophotometer DR 2800 Hach Lange (www.hach.com) was applied for the water quality analysis for variables $\mathrm{NO}_{3}-\mathrm{N}, \mathrm{Fe}, \mathrm{Cl}, \mathrm{F}, \mathrm{Na}, \mathrm{SO}_{4}, \mathrm{Mg}$, $\mathrm{CaCO}_{3}$, Ca and Mn. Turbidity was determined with a Turbicheck Turbidity Meter (Lovibond Water Testing, Tintometer Group, Division Street, Chicago, IL, USA) (Al-Isawi et al., 2015 a, b; Al-Isawi et al., 2017). The $\mathrm{pH}$ for all samples was measured using a VARIO $\mathrm{pH}$ meter (Wissenschaftlich-Technische Werkstätten, Weilheim, Germany) (Al-Isawi et al., 2015a, b). This meter was calibrated with standard buffer solutions of $\mathrm{pH} \mathrm{4,} 7$ and 9 each two weeks or whenever required. The Total Dissolved Solids (TDS) were measured using a Mettler Toledo Education Line Conductivity Meter (Boston Road, Leicester, UK). The packaging's included 10 imported items and 5 domestic items, Table 1 , showing the names of the domestic and imported items studied as well as water quality, raw water sources and packing city.

In order to investigate statistically significant differences, the Shapiro-Wilk's test (Shapiro and Wilk, 1965; Razali and Wah, 2011) was used to assess the normality of data all data were non-normal distribution. A Mann-Whitney test was used to analyse non-normal data
Table 1: Locally produced and imported bottled water

\begin{tabular}{|c|c|c|}
\hline $\begin{array}{l}\text { Type of bottled water/ } \\
\text { Name of bottled water }\end{array}$ & Source of water & Country of origin \\
\hline \multicolumn{3}{|l|}{ Imported } \\
\hline Muen & $(\mathrm{n} / \mathrm{a})^{\mathrm{a}}$ & $\mathrm{KSA}^{\mathrm{b}}$ \\
\hline Alwadi & Fatima valley & $\mathrm{KSA}^{\mathrm{b}}$ \\
\hline Zalal & $(\mathrm{n} / \mathrm{a})^{\mathrm{a}}$ & $\mathrm{KSA}^{\mathrm{b}}$ \\
\hline Aquafina & $(\mathrm{n} / \mathrm{a})^{\mathrm{a}}$ & Kuwait \\
\hline Abraj & $(\mathrm{n} / \mathrm{a})^{\mathrm{a}}$ & Kuwait \\
\hline Faihaa & $(\mathrm{n} / \mathrm{a})^{\mathrm{a}}$ & $\mathrm{KSA}^{\mathrm{b}}$ \\
\hline Raudhtain & Raudhtain field & Kuwait \\
\hline Hania & $(\mathrm{n} / \mathrm{a})^{\mathrm{a}}$ & $\mathrm{KSA}^{\mathrm{b}}$ \\
\hline Delta & $(\mathrm{n} / \mathrm{a})^{\mathrm{a}}$ & $\mathrm{KSA}^{\mathrm{b}}$ \\
\hline Algdeer & $(\mathrm{n} / \mathrm{a})^{\mathrm{a}}$ & $\mathrm{KSA}^{\mathrm{b}}$ \\
\hline \multicolumn{3}{|l|}{ Locally } \\
\hline Sawa & $(\mathrm{n} / \mathrm{a})^{\mathrm{a}}$ & Iraq/Samawah \\
\hline Alraya & $(\mathrm{n} / \mathrm{a})^{\mathrm{a}}$ & Iraq/Samawah \\
\hline Razan & $(\mathrm{n} / \mathrm{a})^{\mathrm{a}}$ & Iraq/Karbala \\
\hline Alkhazer & $(\mathrm{n} / \mathrm{a})^{\mathrm{a}}$ & Iraq/Karbala \\
\hline Salsabeel & $(\mathrm{n} / \mathrm{a})^{\mathrm{a}}$ & Iraq/Karbala \\
\hline
\end{tabular}

(Stoline, 1981; Kasuya, 2001). The Mann-Whitney tests were used to compare means between different treatments. Significant findings have been outlined and discussed. Somehow surprising and/or important insignificant findings have occasionally been highlighted as well.

\section{RESULTS AND DISCUSSION}

Domestic and imported water quality: Table 2 and 3 show the values of arithmetic average of the measurements of quality standards (intended as a statistical term) of two packaging water for each domestic and imported item, respectively indicating the values of the standards contained in the specifications of the bottled drinking water issued by the Saudi Arabian authority. The two tables also included the number of items that did not meet the required specifications. A code of one character and a number for each of the tested items was given to avoid mentioning the trade names, representing the character $(\mathrm{L})$ of the domestic items and the character (I) of the imported items, Fig. 1 and 2 show the value of the arithmetic mean for elements reading of the domestic and imported items in case of high and low readings. A Mann-Whitney test (Nonparasmetric statistics) was used to determine whether the mean values of water standards for domestic varieties were statistically different from those in imported water.

pH: The $\mathrm{pH}$ values of the domestic varieties water varied from 7.1-7.8 (mean value was 7.34) and for the imported items from 7.2-7.8 (mean value was 7.48) and by comparing the results with Saudi Arabian Standard Specifications which determine the value of $\mathrm{pH}$ between 6.5 and 8.5, the researchers found that both the domestic and imported items conform to the specifications with a significant $(\mathrm{p}>0.05)$ differences between them. 
J. Eng. Applied Sci., 14 (Special Issue 9): 10572-10578, 2019

Table 2: The quality measurements results of drinking water for the local items

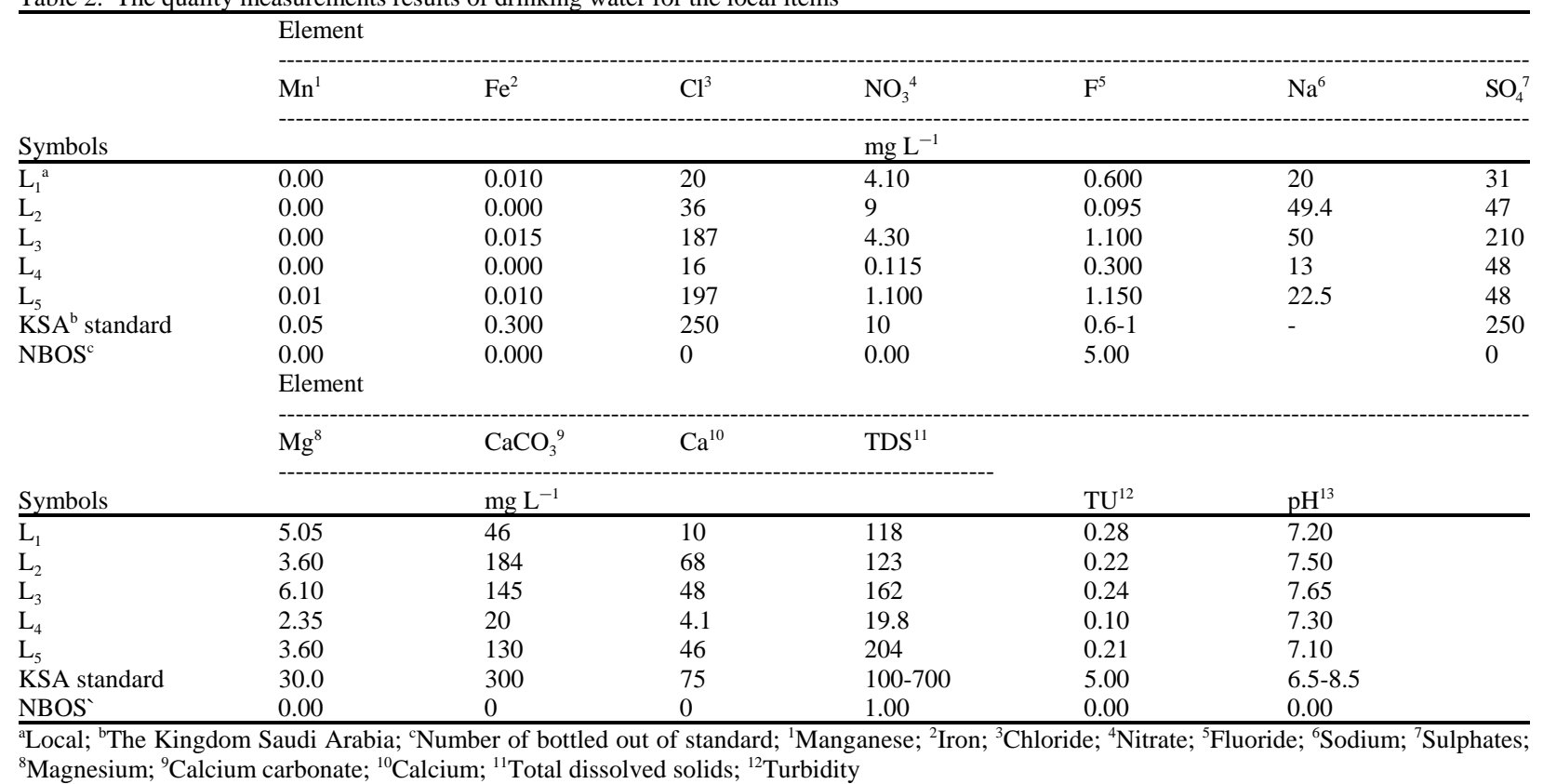

${ }^{8}$ Magnesium; ${ }^{9}$ Calcium carbonate; ${ }^{10}$ Calcium; ${ }^{11}$ Total dissolved solids; ${ }^{12}$ Turbidity

Table 3: The quality measurements results of drinking water for imported items

\begin{tabular}{|c|c|c|c|c|c|c|c|}
\hline \multirow[b]{3}{*}{ Symbols } & \multicolumn{7}{|l|}{ Element } \\
\hline & $\mathrm{Mn}^{1}$ & $\mathrm{Fe}^{2}$ & $\mathrm{Cl}^{3}$ & $\mathrm{NO}_{3}{ }^{4}$ & $\mathrm{~F}^{5}$ & $\mathrm{Na}^{6}$ & $\mathrm{SO}_{4}{ }^{7}$ \\
\hline & \multicolumn{7}{|l|}{$\mathrm{mg} \mathrm{L}^{-1}$} \\
\hline $\mathrm{I}_{1}^{\mathrm{a}}$ & 0.0005 & 0.010 & 20 & 4.1 & 0.6 & 20 & 31 \\
\hline $\mathrm{I}_{2}$ & 0.0000 & 0.000 & 22 & 5 & 0.9 & 22 & 25.6 \\
\hline $\mathrm{I}_{3}$ & 0.0 & 0.005 & 18 & 0.2 & 0.2 & 17 & 54 \\
\hline $\mathrm{I}_{4}$ & 0.001 & 0.000 & 56 & 1.3 & 0.7 & 11 & 19 \\
\hline$I_{5}$ & 0.0 & 0.015 & 21 & 0.6 & 0.7 & 19 & 33 \\
\hline$I_{6}$ & 0.0 & 0.010 & 21 & 7.1 & 0.6 & 9 & 34 \\
\hline $\mathrm{I}_{7}$ & 0.0 & 0.010 & 15 & 4.51 & 0.8 & 12 & 51.5 \\
\hline $\mathrm{I}_{8}$ & 0.0 & 0.010 & 4.5 & 0.1 & 0.2 & 1 & 2.2 \\
\hline $\mathrm{I}_{9}$ & 0.0 & 0.000 & 43 & 6 & 0.67 & 19 & 5.95 \\
\hline $\mathrm{I}_{10}$ & 0.0 & 0.010 & 22.15 & 6.9 & 0.85 & 21 & 14 \\
\hline $\mathrm{KSA}^{\mathrm{b}}$ standard & 0.05 & 0.300 & 250 & 10 & $0.6-1$ & - & 250 \\
\hline \multirow[t]{3}{*}{ NBOS $^{c}$} & 0.00 & 0.000 & 0 & 0 & 2 & & 0 \\
\hline & \multicolumn{7}{|l|}{ Element } \\
\hline & $\mathrm{Mg}^{8}$ & $\mathrm{CaCO}_{3}{ }^{9}$ & $\mathrm{Ca}^{10}$ & TDS $^{11}$ & $\mathrm{TU}^{12}$ & $\mathrm{pH}^{13}$ & \\
\hline Symbols & \multicolumn{7}{|l|}{$\mathrm{mg} \mathrm{L}^{-1}$} \\
\hline$\overline{\mathrm{I}_{1}^{\mathrm{a}}}$ & 5.05 & 46 & 10 & 118 & 0.28 & 7.2 & \\
\hline $\mathrm{I}_{2}^{\mathrm{b}}$ & 7.7 & 45.5 & 5.5 & 105 & 0.23 & 7.2 & \\
\hline $\mathrm{I}_{3}^{\mathrm{c}}$ & 19.5 & 105 & 10 & 120 & 0.18 & 7.8 & \\
\hline $\mathrm{I}_{4}{ }^{\mathrm{d}}$ & 10.55 & 101 & 23 & 111 & 0.1 & 7.65 & \\
\hline $\mathrm{I}_{5}{ }^{\mathrm{e}}$ & 1.8 & 50 & 22.5 & 112 & 0.22 & 7.4 & \\
\hline $\mathrm{I}_{6}^{\mathrm{f}}$ & 6.45 & 121.5 & 38 & 159 & 0.26 & 7.7 & \\
\hline $\mathrm{I}_{7}^{\mathrm{g}}$ & 13.4 & 95 & 16.5 & 114 & 0.115 & 7.2 & \\
\hline $\mathrm{I}_{8}{ }^{\mathrm{h}}$ & 5.55 & 50 & 10.7 & 50 & 0.23 & 7.65 & \\
\hline $\mathrm{I}_{9}^{\mathrm{i}}$ & 17.6 & 110 & 15 & 139 & 0.4 & 7.3 & \\
\hline $\mathrm{I}_{10}^{\mathrm{j}}$ & 8.5 & 75 & 16 & 120 & 0.16 & 7.7 & \\
\hline KSA standard & 30 & 300 & 75 & $100-700$ & 5 & $6.5-8.5$ & \\
\hline NBOS & 0 & 0 & 0 & 1 & 0 & 0 & \\
\hline
\end{tabular}

${ }^{a}$ Imported; ${ }^{b}$ The Kingdom Saudi Arabia; ${ }^{c}$ Number of bottled out of standard; ${ }^{1}$ Manganese; ${ }^{2}$ Iron; ${ }^{3}$ Chloride; ${ }^{4}$ Nitrate; ${ }^{5}$ Fluoride; ${ }^{6}$ Sodium; ${ }^{7}$ Sulphates; ${ }^{8}$ Magnesium; ${ }^{9}$ Calcium carbonate; ${ }^{10}$ Calcium; ${ }^{11}$ Total dissolved solids; ${ }^{12}$ Turbidity

Turbidity (TU): The range of turbidity for the domestic items was (0.1-0.24; 0.195 as a mean value) and for the imported items was (0.1-0.4; 0.217 as a mean value). Both of them were characterized by low levels of turbidity 


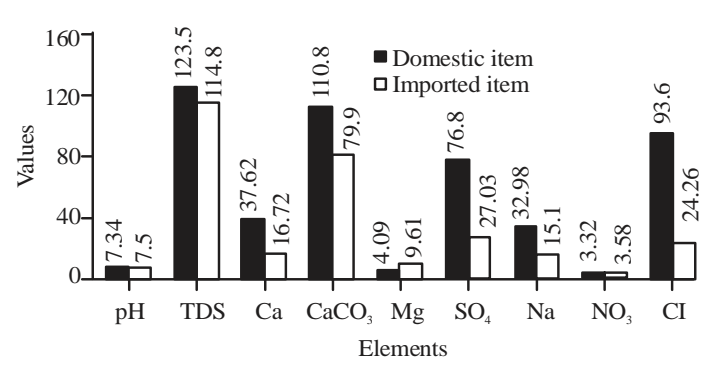

Fig. 1: Values of the arithmetic mean for elements reading of the domestic and imported items for high reading

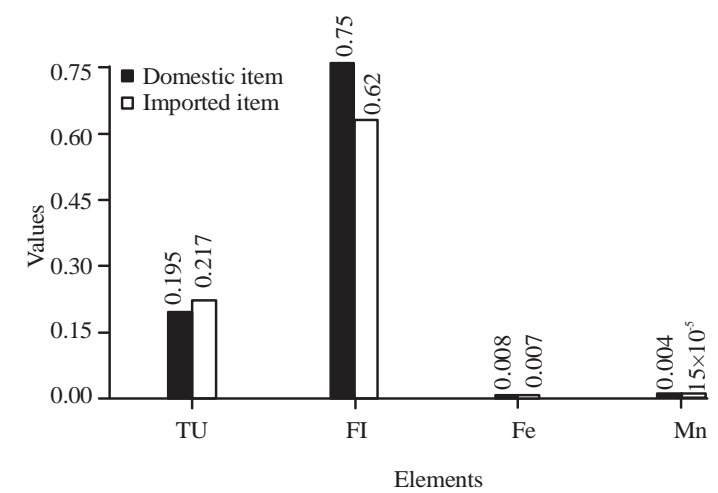

Fig. 2: Values of the arithmetic mean for elements reading of the domestic and imported items for low readings

when compared to the upper limit allowed in the specifications of the World Assembly for bottled drinking water and the United States Food and Drug Administration as shown in Table 2 and 3, respectively. There was no significant $(\mathrm{p}<0.05)$ differences between them as shown in Fig. 2.

Total Dissolved Solids (TDS): Concentration of total dissolved solids for domestic items ranged from (19.8-204, $123.5 \mathrm{mg} \mathrm{L}^{-1}$ as a mean value) and for imported items from (50-159, $114.8 \mathrm{mg} \mathrm{L}^{-1}$ as a mean value). This means that all measured concentrations are below the upper limit allowed in Saudi Arabian specifications, noting that there is a domestic item and an imported item below the minimum limit In Saudi Arabian specifications as shown in Table 2 and 3 and Fig. 1 . There was no significant $(p<0.05)$ differences between them.

Calcium (Ca): The concentration of the Calcium in domestic varieties ranged from (4.1-68 $37.62 \mathrm{mg} \mathrm{L}^{-1}$ ) as a mean value) and in items imported from 5.5-38, $16.72 \mathrm{mg} \mathrm{L}^{-1}$ as a mean value). These values did not exceed the upper limit allowed in Saudi Arabian specifications as shown in Table 2 and 3 and Fig. 1. There was no significant $(\mathrm{p}<0.05)$ differences between them.
Total hardness $\left(\mathrm{CaCO}_{3}\right)$ : The concentration of total hardness in domestic varieties ranged between (20-184 , $110.8 \mathrm{mg} \mathrm{L}^{-1}$ as a mean value) as a calcium carbonate while the concentration of total hardness in imported varieties ranged between (45.5-121.5, $79.9 \mathrm{mg} \mathrm{L}^{-1}$ ) as a mean value) as calcium carbonate as shown in Fig. 1 and by comparing the median values, the researchers found that the median value of the items Domestic (110.8 $\mathrm{mg} \mathrm{L}^{-1}$ ) higher than the median value of imported items (79.9 $\mathrm{mg} \mathrm{L}^{-1}$ ) by $38 \%$ with note that all domestic and imported items did not exceed the upper limit allowed in Saudi Arabian specifications as shown in Table 2 and 3 . There was no significant $(\mathrm{p}<0.05)$ difference between them.

Magnesium (Mg): The concentration of magnesium in domestic varieties ranged between (2.35-6.1, $4.09 \mathrm{mg} \mathrm{L}^{-1}$ as a mean value) while the concentration in the imported varieties ranged from (1.8-17.6 9.61 $\mathrm{mg} \mathrm{L}^{-1}$ ) as a mean value) as shown in Fig. 1 with a significant $(p>0.05)$ difference between them. All domestic and imported items are identical to Saudi Standard Specifications as they do not exceed the maximum allowable limit as shown in Table 2 and 3.

Sulphate $\left(\mathbf{S O}_{4}\right)$ : Domestic varieties contained sulfate with concentrations of $31-210,67.8 \mathrm{mg} \mathrm{L}^{-1}$ as a mean value) and imported items between (2.2-54, $27.03 \mathrm{mg} \mathrm{L}^{-1}$ as a mean value) as shown in Fig. 1 and the median value of the domestic items $\left(67.8 \mathrm{mg} \mathrm{L}^{-1}\right)$ is approximately three times the median value of the imported items (27.03 $\left.\mathrm{mg} \mathrm{L}^{-1}\right)$ with no significant $(\mathrm{p}<0.05)$ difference between them. All domestic and imported items are identical to Saudi Standard Specifications as they do not exceed the maximum allowable limit as shown in Table 2 and 3.

Sodium (Na): Domestic sodium varieties contained a higher concentration of imported items with concentrations in domestic varieties ranging from (13-50, $32.98 \mathrm{mg} \mathrm{L}^{-1}$ as a mean value) while in imported items between (1-22 $15.1 \mathrm{mg} \mathrm{L}^{-1}$ as a mean value) as shown in Fig. 1 with no significant $(\mathrm{p}<0.05)$ difference between them. Saudi standard specifications did not specify a value for the allowable level of sodium in bottled drinking water but Iraqi Standard Specifications for bottled drinking water stipulate that sodium concentration shall not exceed $\left(200 \mathrm{mg} \mathrm{L}^{-1}\right)$.

Fluoride (F): Fluoride concentration in domestic varieties ranged between $\left(0.095-1.15,0.75 \mathrm{mg} \mathrm{L}^{-1}\right)$ as a mean value) and in imported items $\left(0.2-0.9,0.62 \mathrm{mg} \mathrm{L}^{-1}\right.$ as a mean value) as shown in Fig. 2 with no significant $(p<0.05)$ difference between them. It is clear that two imported items do not conform to Saudi Standard 
Specifications while all domestic items are not matched Saudi Standard Specifications as shown in Table 3. Lewis, 1996 and Spellman, 2014 demonstrated that drinking water containing fluoride with a concentration of $1.0 \mathrm{mg} \mathrm{L}^{-1}$ helps in reducing the incidence of tooth decay by $65 \%$ for children between $12-15$ years while increasing fluoride concentration more than $2 \mathrm{mg} \mathrm{L}^{-1}$ the grey or black spots appear on the children's permanent fingers are accompanied by a necrosis of the tooth and this is known as fluorosis. Furthermore, if fluoride concentration in drinking water is more than $\left(8.0 \mathrm{mg} \mathrm{L}^{-1}\right)$ this leads to hardening of cartilage and bones because of its accumulation, leading to hardening of the spine and difficulty bending.

Nitrate ( $\left.\mathbf{N O}_{3}\right)$ : Nitrate concentrations in domestic varieties ranged from $\left(0.115-9,3.32 \mathrm{mg} \mathrm{L}^{-1}\right.$ as a mean value), higher than nitrate concentration in imported items (0.1-9, $3.58 \mathrm{mg} \mathrm{L}^{-1}$ as a mean value) as shown in Fig. 2 with no significant $(\mathrm{p}<0.05)$ difference between them. The nitrate concentration in the domestic and imported varieties did not exceed the upper limit allowed in Saudi Arabian specifications as described in Table 2 and 3, respectively.

Chlorides (Cl): Concentrations of chlorides in domestic varieties are higher than in imported items where the concentration in domestic varieties ranged between (16-197,93.6 $\mathrm{mg} \mathrm{L}^{-1}$ as a mean value) and imported items between (4.5-56, $24.26 \mathrm{mg} \mathrm{L}^{-1}$ as a mean value) as shown in Fig. 1 with no significant $(\mathrm{p}<0.05)$ difference between them. The concentration of chlorides in both of domestic and imported items did not exceed the upper limit allowed in Saudi Standard specifications as shown in Table 2 and 3 , respectively.

Iron (Fe): The concentration of iron in the domestic varieties ranged between $\left(0.0-0.015,0.004 \mathrm{mg} \mathrm{L}^{-1}\right.$ as a mean value) and in the imported items between (0.0-0.015, $0.0002 \mathrm{mg} \mathrm{L}^{-1}$ as a mean value) as shown in Fig. 2 with a significant $(\mathrm{p}<0.05)$ difference between them. All domestic and imported items did not exceed the upper limit allowed in Saudi specifications as shown in Table 2 and 3, respectively.

Manganese (Mn): Domestic varieties, the manganese concentration ranged between $\left(0.0-0.01,0.004 \mathrm{mg} \mathrm{L}^{-1}\right.$ as a mean value) and in the imported items between (0.0-0.001, $0.00015 \mathrm{mg} \mathrm{L}^{-1}$ as a mean value) as shown in Fig. 2, noting that the median value of the domestic items $\left(0.004 \mathrm{mg} \mathrm{L}^{-1}\right)$ is equivalent to about two and a half times the median value of the imported items $\left(0.00015 \mathrm{mg} \mathrm{L}^{-1}\right)$ with a significant $(\mathrm{p}<0.05)$ difference between them. All domestic and imported items did not exceed the maximum allowable limit in Saudi Arabian specifications as shown in Tables 2 and 3, respectively.

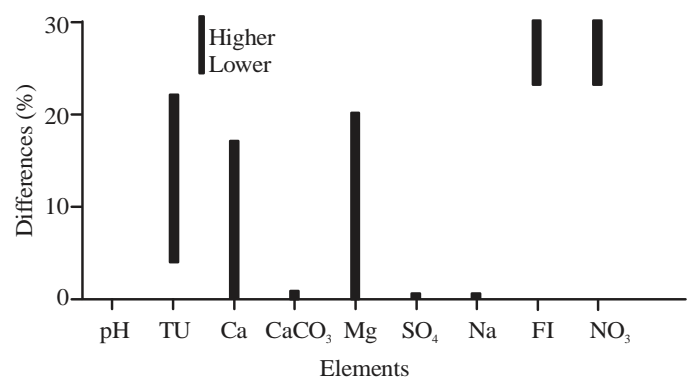

Fig. 3: Percentages difference for each element in case of domestic packaging

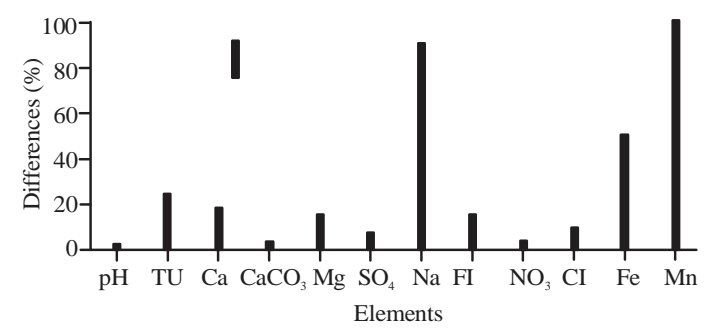

Fig. 4: Percentages difference for each elements in case of imported packaging

Comparison of the quality of the packaging water for one element: Laboratory tests of the two items tested for each of the different domestic and imported bottled water showed that the test results for some of the elements (from 5-10 variables) were equal in the two packages while the other elements differed in varying proportions ranging from (0-35\%) in case of domestic items and $(0-100 \%)$ in case of imported items as shown in Fig. 3 and 4, respectively. In the domestic varieties, the percentages difference between the two packaging for the $\mathrm{pH}, \mathrm{TU}, \mathrm{Ca}$, Hardness, $\mathrm{Mg}, \mathrm{SO}_{4}, \mathrm{Na}, \mathrm{Fl}$ and $\mathrm{NO}_{3}$ were $0-2,4-22,0-17,0-1,0-20,0-0.5,0-0.5,10-35$ and 23-30, respectively. While laboratory tests for TDS, Cl, F and $\mathrm{MN}$ did not record any percentages of difference. In case of imported items, the percentages difference between The two packaging of $\mathrm{pH}$, TU, TDS, Ca, Hardness, $\mathrm{Mg}, \mathrm{SO}_{4}, \mathrm{Na}, \mathrm{Fl}, \mathrm{NO}_{3}, \mathrm{Cl}, \mathrm{F}$ and $\mathrm{Mg}$ were $0-3$, $0-25,0-3,0-18,0-4,0-15,0-8,0-90,0-16,0-4,0-10,0-50$ and $0-100$, respectively.

Comparison of the quality of water packaged with the content on the packaging: Of the 13 quality standards carried out, two of them did not mention any concentration in the domestic and imported varieties, namely, TU and Mn. All domestic and two of imported varieties did not mention Fl concentration. Total hardness was not mentioned in Four domestic and six imported items. the nitrate concentration was not mentioned in four domestic varieties and two items of imported. TDS was 


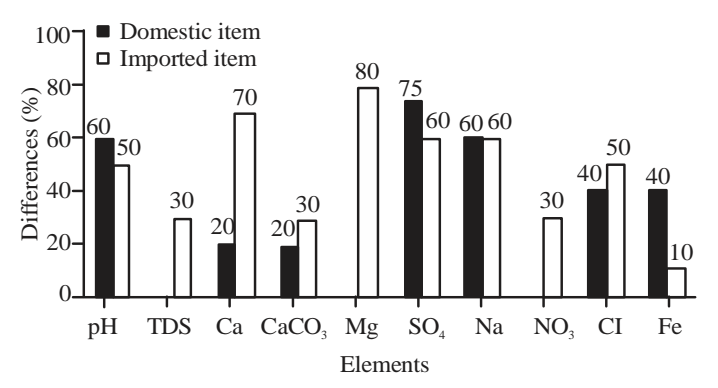

Fig. 5: Comparison of the percentage of domestic and imported varieties that exceeded the mentioned concentrations in their packaging for each element

not mentioned in three domestic varieties and two imported items. Iron concentration was not mentioned in three domestic varieties and four imported items. Figure 5 compare the proportion of domestic and imported bottled water that have exceeded their packaging for element.

\section{CONCLUSION}

Domestic and imported items have achieved good quality in all physical and chemical standards except for two criteria, namely, total dissolved solids and fluoride where one domestic item and one imported item did not achieve the level of concentration of dissolved solids and all domestic items were not specifications are achieved in fluoride concentration while two imported items did not achieve the specifications in fluoride concentration.

Statistical analysis using the Mann-Whitney test at the significance level 0.05 , the quality of the domestic varieties is no different from the quality of the imported items in the following criteria: turbidity, dissolved solids, total hardness, calcium, sodium, fluoride, nitrate, sulphate and chlorides, the quality varies in the following criteria: $\mathrm{pH}$, magnesium, iron and manganese.

There is a variation in the water quality of the same item as the measurement of the two packaging's tested for each item revealed a difference in the values of the standards in varying proportions ranging $(0-35 \%)$ for domestic items and $(0-100 \%)$ for imported items which indicates the irregularity of the efficiency of the water purification processes in the factory, the difference in the quality of the raw water over time and the multiplicity of water sources of one factory.

There is a significant discrepancy between the values of the measured standards and their stated values on the packaging's except for dissolved solids, magnesium and nitrates in domestic varieties and iron in imported items.

\section{RECOMMENDATIONS}

Some domestic items need to be added fluoride and others need to be reduced in fluoride either for imported items, some of which need to be increased fluoride.

Relevant agencies must take their oversight role from monitoring all stages of packaged water factories and their water sources and carrying out periodic checks on the water produced from these factories for domestic items. Imported items must be subject to laboratory tests from time to time to ensure that they conform to standard specifications.

\section{REFERENCES}

APHA., 1995. Standard methods for the examination of water and wastewater. American Public Health Association (APHA), ?Washington, DC., USA.

Al-Isawi, R., M. Scholz, Y. Wang and A. Sani, 2015b. Clogging of vertical-flow constructed wetlands treating urban wastewater contaminated with a diesel spill. Environ. Sci. Pollut. Res., 22: 12779-12803.

Al-Isawi, R., S. Ray and M. Scholz, 2017. Comparative study of domestic wastewater treatment by mature vertical-flow constructed wetlands and artificial ponds. Ecol. Eng., 100: 8-18.

Al-Isawi, R.H.K., A. Sani, S.A.A.A.N. Almuktar and M. Scholz, 2015a. Vertical-flow constructed wetlands treating domestic wastewater contaminated by hydrocarbons. Water Sci. Technol., 71: 938-946.

Huerta-Saenz, L., M. Irigoyen, J. Benavides and M. Mendoza, 2012. Tap or bottled water: Drinking preferences among urban minority children and adolescents. J. Community Health, 37: 54-58.

Hussein, A. and M. Scholz, 2017. Dye wastewater treatment by vertical-flow constructed wetlands. Ecol. Eng., 101: 28-38.

Hussein, A., 2017. AZO textile dyes wastewater treatment with constructed wetlands: design and operation of experimental vertical-flow constructed wetlands applied for the treatment of azo textile dyes (with/without artificial wastewater). Ph.D Thesis, University of Salford, Greater Manchester, England.

Johnstone, N. and Y. Serret, 2012. Determinants of bottled and purified water consumption: Results based on an OECD survey. Water Policy, 14: 668-679.

Kasuya, E., 2001. Mann-Whitney U test when variances are unequal. Anim. Behav., 61: 1247-1249.

Lewis, S.A., 1996. The Sierra Club Guide to Safe Drinking Water. Sierra Club Books, San Francisco, California, USA., ISBN:9780871563552, Pages: 113.

Olson, E.D., D. Poling and G. Solomon, 1999. Bottled water: Pure drink or pure hype?. Master Thesis, Natural Resources Defense Council, New York, USA. 
Razali, N.M. and Y.B. Wah, 2011. Power comparisons of shapiro-wilk, kolmogorov-smirnov, lilliefors and anderson-darling tests. J. Stat. Model. Anal., 2: 21-33.

Shapiro, S.S. and M.B. Wilk, 1965. An analysis of variance test for normality (Complete samples). Biometrika, 52: 591-611.

Sharma, J.K., 2010. Quantitative Methods: Theory and Applications. Macmillan Publishers India Limited, Noida, India, ISBN:9780230328716, Pages: 864.
Spellman, F.R., 2014. The Science of Water: Concepts and Applications. 3rd Edn., CRC Press, Boca Raton, Florida, USA., ISBN:9781482242935, Pages: 550.

Stoline, M.R., 1981. The status of multiple comparisons: Simultaneous estimation of all pairwise comparisons in one-way ANOVA designs. Am. Statistician, 35: 134-141.

Viessman, W., 2009. Water Supply and Pollution Control. 8th Edn., Pearson Prentice Hall, Upper Saddle River, New Jersey, USA., ISBN:9780132337175, Pages: 843. 